\title{
SUFISME DALAM SYAIR HAMZAH FANSURI
}

\author{
Haryadi \\ Fakultas Bahasa dan Seni Universitas Negeri Yogyakarta \\ e-mail: haryadi_uny@uny.ac.id
}

\begin{abstract}
Abstrak
Penelitian ini bertujuan mengungkapkan visi ketuhanan, visi keduniaan, dan konsep pendekatan diri kepada Tuhan bagi Hamzah Fansuri. Sumber data penelitian adalah Syair Perahu I dan Syair Perahu II yang telah ditranskripsikan oleh Braginsky. Pengumpulan data dilakukan dengan cara membaca berulang-ulang. Teknik analisis data yang digunakan adalah deskriptif kualitatif dengan referensi keilmuan tentang sastra dan tasawuf. Berdasarkan kajian literer dihasilkan tiga kesimpulan. Pertama, kedekatan manusia dengan Tuhan menurut Hamzah Fansuri dapat sampai pada tataran tertinggi, yaitu menyatunya hamba dengan khalik. Kedua, Hamzah Fansuri memandang dunia sebagai suatu yang bersifat fana, sedangkan akhirat merupakan sesuatu yang bersifat baka. Ketiga, konsep Hamzah Fansuri dalam mendekatkan diri kepada Tuhan ialah (a) ingat akan diri sendiri, (b) berzikir dan mengucapkan puji-pujian, (c) beramal sholeh, (d) mengekang hawa nafsu dan hidup sederhana, dan (e) nahi mungkar.
\end{abstract}

Kata kunci: sufisme, syair, visi ketuhanan, visi kemanusiaan

\section{SUFISM IN HAMZAH FANSURI'S POEMS}

\begin{abstract}
This study aims to reveal the divine vision, worldly vision, and concept of making the self close to God according to Hamzah Fansuri. The data sources were Syair Perahu I and Syair Perahu II transcribed by Braginsky. The data were collected through repeated reading. They were analyzed using the qualitative descriptive technique with a reference to literary and sufism theories. The study reveals three conclusions. First, according to Hamzah Fansuri, human beings' closeness to God can reach the highest level, namely the unification of the creature and the creator. Second, Hamzah Fansuri views the world as something temporary and the life after as something eternal. Third, Hamzah Fansuri's concept of making the self close to God includes (a) being aware of the self, (b) remembering God and expressing praises, (c) performing good deeds, (d) controlling the passion and living simple life, and (e) avoiding evil deeds.
\end{abstract}

Keywords: sufism, poems, divine vision, humanity vision

\section{PENDAHULUAN}

Sejak akhir abad ke-14 dan terutama sekali abad ke-16 s.d. 17 sufisme atau tasawuf telah memainkan peranan yang sangat penting dalam sejarah, agama, dan kebudayaan di kawasan MelayuIndonesia. Salah seorang tokohnya adalah Hamzah Fansuri. Beliau adalah guru Syamsudin Pasai, seorang sufi dan penasi- hat agama Sultan Iskandar Muda, yang wafat pada tahun 1630. Hamzah Fansuri bukan hanya dikenal sebagai seorang ulama tasawuf tetapi seorang perintis dan pelopor perkembangan kebudayaan Islam, sekaligus seorang sastrawan terkemuka.

Di bidang sastra Hamzah Fansuri memelopori penulisan puisi-puisi filosofis 
dan mistis bercorak Islam. Karya puisinya sangat banyak, misalnya (1) Syair Perahu, (2) Syair Burung Pingai, (3) Anggur, (4) Kekasih, (5) Kapal dan Laut, (6) Syair Bahr an-Nisa. Dalam perkembangannya rintisan Hamzah Fansuri di bidang sastra sufi telah mendapat tempat pada karya-karya Pujangga Baru seperti Amir Hamzah, dan beberapa sastrawan Angkatan 70-an seperti Danarto dan Sutardji Calszoom Bachri

Sufisme yang dikembangkan oleh Hamzah Fansuri mendapat kecaman dari ulama yang lain. Syekh Nuruddin ar-Raniri, salah seorang ulama kesultanan Aceh, ketika itu menyatakan bahwa ajaran tasawuf Hamzah Fansuri termasuk ajaran kaum zindik dan panteis. Buku Hamzah Fansuri dibakar dan hanya sedikit yang dapat diselamatkan.

Sufisme Hamzah Fansuri yang dituduh menyimpang dari ajaran Islam dapat dikaji melalui syair-syairnya, terutama Syair Perahu I dan Syair Perahu II. Braginsky (1993:130) pernah mengutip salah satu bait dari puisi itu untuk memberikan gambaran tentang paham tasawuf yang dianut Hamzah Fansuri / Itulah laut yang maha indah/Ke sanalah kita semuanya berpindah/Hasilkan bekal kayu dan juadah/Selamatlah engkau sempurna musyahadah.//

Dari kajian itu dapat diketahui (1) Bagaimana visi ketuhanan Hamzah Fansuri?, (2) Bagaimana visi keduniaan Hamzah Fansuri?, dan (3) Bagaimana konsep Hamzah Fansuri dalam pendekatan diri kepada Tuhan? Selanjutnya, dengan merujuk pada Alquran dan hadis dapat diketahui penyimpangaan Hamzah Hanfuri dari ajaran Islam. Ada tiga tujuan yang ingin dicapai dalam penelitian ini yaitu mengetahui tentang (1) visi ketuhanan Hamzah Fansuri, (2) visi keduniaan Hamzah Fansuri, dan (3) konsep Hamzah Fansuri dalam pendekatan diri kepada Tuhan.

Hasil penelitian ini akan memperluas wawasan masyarakat tentang sufisme.
Dengan demikian, mereka dapat memberikan apresiasi positif terhadap sufisme dan memanfaatkannya dalam kehidupan modern. Sementara itu, dalam bidang pendidikan, hasil penelitian dapat memperkaya materi perkuliahan terutama sastra klasik.

Sufisme adalah istilah lain dari tasawuf. Para orientalis barat memaknai istilah itu dengan mistisisme dalam Islam. Dalam buletin Uswatun Hasanah (04/Th. I Shafar 1410 H/September 1989) dijelaskan bahwa tasawuf dalam ilmu pengetahuan dikenal dengan nama "mistisisme dalam Islam", dan kaum orientalis barat menyebutkan dengan sufisme. Mistisisme sebagai suatu istilah bersifat universal, oleh karena hampir semua ajaran agama ada segi mistisnya. Mistisisme erat berkaitan dengan kata mistery, atau mysterious yang berarti rahasia. Oleh kerena itu wajar apabila orang mengatakan mistisisme atau sufisme sulit untuk dipahami.

Tasawuf berasal dari kata sufi. Kata sufi berasal dari shaafaa dan shafaa yang berarti suci. Seorang sufi adalah orang yang disucikan. Kaum sufi adalah orangorang yang telah menyucikan dirinya melalui latihan yang berat dan lama. Hatta (1983:48) mengatakan bahwa orang yang mula-mula digelari sufi ialah Abu Hasyim dari Koufah, yang wafat tahun $150 \mathrm{H}(761 \mathrm{M})$.

Sufi menurut Hatta (1982:48) berasal dari suufun yang berarti kain terbuat dari bulu atau wol. Hal itu merupakan simbol kesederhanaan. Mereka, kaum sufi, hidup sederhana dan dalam keadaaan miskin tetapi suci atau mulia. Dalam kenyataan sejarah muncul orang-orang yang berpakaian sederhana, pakaiannya terbuat dari buku domba, dan mereka meninggalkan kemewahan yang sering dilambangkan dengan kain sutera.

Sukmono (1973:15) berpendapat tasawuf adalah semacam ilmu (cara) untuk mendekatkan diri kepada Tuhan, dalam mana orang-orang yang melaksanakannya memakai pakaian dari bulu domba 
dan hidup sederhana sekali. Dalam Kamus Besar Bahasa Indonesia (1995:660) tasawuf disejajarkan dengan suluk, mistik yaitu subsistem yang ada dalam hampir semua agama dan sistem religi untuk memenuhi hasrat manusia mengalami dan merasakan emosi bersatu dengan Tuhan.

Sufisme tampaknya akan tetap eksis sepanjang zaman. Meskipun sekarang keadaan sudah berbeda, ilmu pengetahuan dan teknologi berkembang pesat, dan kebudayaan modern telah menyebar ke berbagai aspek kehidupan, tampaknya paham tasawuf tetap relevan. Kuntowidjojo (Tempo, 1991 Th. 21 No. 8:76) melihat kecenderungan orang belajar tasawuf sekarang ini ibarat mencari oase di padang pasir. Ketika ekonomi membaik, hidup cenderung hedonistik dan bermewah-mewah, muncul kesadaran yang kontradiktif yaitu kehausan pada kesederhanaan. Ekspresinya tampak pada simbol ketasawufan, seperti kesederhanaan, kecintaan, dan kesalihan.

Syahrul Syarif (dalam Hatta, 1982:52) menerangkan bahwa ada empat anasir tasawuf dalam Islam, antara lain (1) anasir hidup Islam dalam abad pertengahan, (2) anasir concentric astrologis, (3) anasir Platonisme, (4) ajaran dari Alquran. Pada abad pertengahan beberapa pengaruh dari luar masuk ke dalam agama Islam, misalnya filsafat Yunani, filsafat Parsi, filsafat India, agam Kristen. Di samping itu, ilmu nujum dan astrologi yang digandrungi masyarakat pada saat itu juga berpengaruh terhadap ajaran Islam. Demikian pula pengaruh datang dari filsafat Plato yang diperbaiki oleh Plotinus. Mereka berpendapat di atas kekuasaan raja masih ada kekuasaan yang lebih tinggi, yang dinamakan ide tertinggi, maksudnya ialah Tuhan. Sudah barang tentu, tasawuf sebagai paham dalam ajaran Islam tidak lepas dari Alquran.

Tasawuf atau sufisme sebagaimana halnya mistisisme di luar agama Islam yaitu mempunyai tujuan memperoleh hubungan langsung dengan Tuhan se- hingga disadari benar bahwa seseorang berada di hadirat Tuhan. Intisari mistisisme ialah kesadaran akan adanya komunikasi dan dialog antara roh manusia di hadapan Tuhan. Cara yang dilakukan dengan jalan mengasingkan diri dan berkomtemplasi. Kesadaran berada dekat dengan Tuhan itu dapat mengambil bentuk ittihad, yaitu bersatu dengan Tuhan. Suatu bentuk yang tertinggi, di samping wihdatul wujud atau hulul.

Mulkan (2002: 35-36) menjelaskan bahwa wihdatul wujud adalah kepercayaan bahwa seluruh yang maujud atau yang ada pada prinsipnya hanyalah satu dalam segala arti yang tidak dapat diduakan. Hal satu maujud itulah Tuhan Allah di mana segala bentuk keragamaan yang tampak dan kasat mata dianggap tidak ada. Mereka percaya bahwa seluruh hal lain di dunia ini tidak lain kecuali hanya gambaran atau bayangan dari yang satu yaitu Tuhan itu sendiri. Sementara itu, hulul merupakan kepercayaan yang menunjuk sebuah ajaran yang menyatakan bahwa Allah bisa bersemayam dalam tubuh seseorang terutama pada diri para mursyid (guru tasawuf)

Tasawuf sebagai ilmu pengetahuan mempelajari bagaimana cara dan jalan bagaimana seseorang Islam dapat berada sedekat mungkin dengan Tuhan. Hatta (1982:59-59) mengemukakan tingkatantingkatan yang mesti dilakukan oleh seorang sufi, yaitu (1) syariat, (2) thariqat, (3) hakikat, dan (4) makrifat. Syariat adalah segala aturan-aturan hukum yang termuat di dalam Alquran dan Sunah Nabi yang harus dilakukan oleh manusia. Thariqat adalah jalan ditempuh untuk mendekatkan diri kepada Tuhan. Dalam hal itu, syariat ibarat teori dan praktiknya ialah thariqat. Hakikat adalah kebenaran sejati (kebenaran mutlak) yang oleh Palto disebut ide tertinggi. Hakikat adalah ujung jalan tempat tujuan terakhir, Sementara itu, makrifat adalah insan kamil atau wihdatul wujud, yaitu manusia sempurna yang mengenal dirinya yang berarti juga 
telah mengenal Tuhannya.

Di masa lampau pengaruh tasawuf terhadap sastra cukup dominan. Dalam masyarakat Melayu terdapat banyak karya sastra yang di dalamnya mengandung ajaran tasawuf, antara lain karyakarya Hamzah Fansuri, baik yang berupa prosa yang sering disebut dengan sastra kitab, maupun karya sastra bentuk puisi yang sering disebut dengan istilah tasawuf puitik.

Hamzah Fansuri adalah seorang cendekiawan, ulama, sastrawan, dan budayawan terkemuka yang diperkirakan hidup antara pertengahan abad ke-16 sampai dengan awal abad ke-17. Sumbangan Hamzah Fansuri sangat besar bagi perkembangan kebudayaan Islam, khususnya di bidang kerokhanian, keilmuan, filsafat, bahasa, dan sastra. Kritikkritiknya yang tajam terhadap perilaku politik dan moral raja-raja, para bangsawan dan orang-orang kaya menempatkannya sebagai seorang intelektual yang berani pada zamannya. Karena itu tidak mengherankan apabila kalangan istana Aceh tidak begitu menyukai kegiatan beliau dan para pengikutnya.

Kitab-kitab Hamzah Fansuri dimusnahkan pada tahun 1637, baik untuk memenuhi perintah Iskandar Tsani (16371641) maupun fatwa Syakh Nurruddin ar Raniri, ulama Aceh ketika itu. Ar Raniri menyatakan dalam khutbah-khutbahnya bahwa ajaran tasawuf Hamzah Fansuri dan Syamsuddin Pasai termasuk ajaran kaum zindik dan panteis. Pada saat itu ribuan buku karangan Hamzah Fansuri ditumpuk di hadapan Masjid Raya Kutaraja untuk dibakar sampai musnah. Hanya sedikit di antara buku-buku itu yang dapat diselamatkan (Hadi WM, 1995: 13).

Di antara karangan Syekh Hamzah Fansuri yang dapat diselamatkan adalah tiga risalah tasawuf dan 33 ikatan syair. Tiga risalah tasawuf itu adalah $A s r a r ~ A l$ Arifin (Rahasia Ahli Makrifat), Syarab Al Asyiqin (Minuman Orang-orang yang
Berahi), dan Al Muntahi. Sementara itu, karya-karya puisi Hamzah Fansuri yang dapat diselamatkan adalah (1) Syair Perahu, (2) Burung Pingai, (3) Anggur, (4) Kekasih, (5) Kapal dan Laut, (6) Syair Bahr An-Nisa.

Sebagai seorang sufi, terutama di dalam cinta ('isy) dan makrifat, Hamzsah Fansuri mengidolakan Bayazzid dan Al Halajj. Di samping itu beliau terpengaruh oleh pemikiran Iraqi dan Ibn Arabi. Dalam hal ini, beliau sering mengutip pernyataan dan syair-syair Iraqi dan Ibn Arabi untuk menopang sufinya.

Menurut Iraqi asas penampakan Tuhan melalui pengetahuan-Nya, yakni wujud-Nya ialah cinta. Dengan kata lain cinta adalah hakikat wujud Tuhan yang melalui itu penampakan sebagian dari pengetahuan-Nya atau hartanya yang tersembunyi (kanz makhfi) dimungkinkan. Itulah sebabnya apabila kaum wujudiah seperti Iraqi dan Jami berbicara tentang cinta (isy) yang dimaksudkan adalah wujud Tuhan, dan wujudnya tidak lain adalah sifat-sifatnya yang tampak melalui kepercayaannya.

Menurut Al Iraqi, Al Jili dan Jami, sifat-sifat Tuhan yang pada hakikatnya adalah cinta sebenarnya telah terkandung di dalam kalimat suci Bismi Allah Al rahman Al Rahim. Di dalam perkataan bismillah itu terdapat dua macam cinta Tuhan, yaitu rahman dan rahim. Rahman dan rahim itu berasal dari perkataan yang sama yaitu rahma (rahmat). Rahman adalah rahmat Tuhan yang bersifat esensial (dzatijah) dan rahim adalah rahmat Tuhan yang bersifat wajib (wujud). Dikatakan esensial karena sifat rahman Tuhan atau wujud rahman-Nya berlaku atas segala ciptaan-Nya dan atas segala manusia. Artinya, segala ciptaan Tuhan di alam semesta ini tidak terbebas dari rahmat-Nya, dan diliputi oleh pengetahuan-Nya yang termanifestasikan karena dorongan cinta. Di lain hal rahim disebut rahmat-Nya yang wajib sebab ia wajib dilimpahkan kepada orang-orang tertentu yang men- 
cintai-Nya dengan penuh kesungguhan, yakni orang mukmin dan muttaqin yang salih, beramar makruf nahi mungkar dan sungguh-sungguh melakukan mujahadah, sehingga akhirnya musyahadah dan mukasyafah. Al Jili mengatakan bahwa rahman mencakup tujuh sifat yang utama, yakni Hayyi (Hidup), 'ilm (Pengetahuan), Iradat (Kehendak), Qudrat (Kuasa), Sami' (Mendengar), Basir (Melihat), dan Kalam (Kata).

\section{METODE}

Sumber data penelitian ini adalah dua buah puisi karya Hamzah Fansuri, yaitu Syair Perahu I (terdiri dari 96 bait) dan Syair Perahu II (terdiri dari 80 bait. Kedua puisi ini dipilih berdasarkan pertimbangan bahwa kedua puisi tersebut sarat dengan pemikiran-pemikiran Hamzah Fansuri tentang tasawuf.

Naskah yang menjadi bahan kajian berasal dari hasil transliterasi yang dilakukan oleh Braginsky (1993). Hal itu terpaksa dilakukan karena peneliti sulit mendapatkan naskah aslinya.

Pengumpulan data dilakukan dengan cara membaca puisi itu secara berulangulang sehingga ditemukan data yang relevan. Instrumen penelitian adalah peneliti sendiri. Proses pencatatan (recording) dilakukan dengan menggunakan kartu data. Satuan data dalam penelitian ini berupa berupa kata, frase, kalimat, dan bait. Teknik analisis data yang digunakan adalah analisis deskriptif kualitatif. Data yang terkumpul selanjutnya diberi kode (coding), diklasifikasikan berdasarkan pokok kajian, dan dimaknai berdasarkan referensi yang menjadi rujukan. Selanjutnya, simpulan diambil secara induktif.

Keabsahan penelitian diuji dengan menggunakan validitas semantik dan intrareter. Validitas semantik dilakukan dengan cara memaknai bagian-bagian dari subjek penelitian itu berdasarkan struktur kalimat atau wacana yang ditampilkan. Sementara itu, intrareter dilakukan dengan cara membaca puisi itu secara cermat dan berulang-ulang sehingga ditemukan data yang benar-benar sesuai dengan pokok kajian. Selanjutnya, kredibilitas penafsiran data penelitian dilakukan dengan diskusi teman sejawat (peer discussion). Dalam hal ini pelaksanaannya dilakukan melalui reviewer dan kegiatan seminar yang melibatkan teman sejawat. Berdasarkan masukan tersebut, akhirnya laporan penelitian disusun dan disempurnakan.

\section{HASIL DAN PEMBAHASAN Visi Ketuhanan Hamzah Fansuri}

Tasawuf merupakan salah satu aliran dalam agama Islam yang berusaha mendekatkan diri kepada Allah, sedekatdekatnya. Istilah 'dekat' dipahami oleh sebagian masyarakat sebagai masih ada jarak antara manusia dengan Tuhan, dan sebagian lagi memahaminya tidak ada perbedaan antara manusia dengan $\mathrm{Tu}-$ hannya. Kaidah itu sebenarnya bertolak dari hadis nabi yang menyatakan Man 'arafaa nafsahu faqad 'arafa rabbahu, artinya "barang siapa mengenal dirinya sendiri maka sesungguhnya dia telah mengenal Tuhannya".

Al Hallaj memahami kedekatan itu sampai pada tahap bersatunya makhluk dengan khaliknya, manusia dengan Tuhannya. Istilah yang lazim digunakan adalah 'anaa al haq' artinya saya adalah al Haq (Tuhan) Paham menyatunya makhluk dengan khalik disebut paham wujudiyah. Paham ini berkembang juga di Indonesia. Tokoh paham tersebut di Melayu adalah Hamzah Fansuri dan Syamsuddin asSumatrani, dan di Jawa adalah Syekh Siti Jenar.

Paham ini di Jawa dikenal dengan istilah 'manunggaling kawula lan Gusti'. Namun, dalam pengertian lain, istilah tersebut dimaknai menyatunya rakyat dan pemimpin, rakyat dan raja. Hal ini sejalan dengan kultur Jawa yang memahami raja atau sultan sebagai khalifatullah yaitu wakil Allah. 
Hamzah Fansuri memahami Tuhan sebagai zat yang memiliki berbagai sifat kemuliaan. Sifat kemuliaan yang disebutkan ialah (1) Rabb al-Alamim, (2) ahadiyat atau esa, (3) kadim, (4) al-Latif, (5) wujud, (6) jalal, (7), jamal, (8) wujud Allah, (9) kamal, (10) iradat atau maha berkehendak, (11) kudrat atau mahakuasa, (12) ghani, (13) Tuhan yang esa, (14) Tuhan yang kekal, (15) Tuhan yang ghafil, (16) hidup (hayat), (17) mahatahu (alim), (18) maha mendengar (sama), (19) melihat (bashar), (20) kalam (berkata). Di dalam ajaran Islam dikenal 20 sifat wajib Allah, seperti wujud (ada), wahdaniyat (esa), kudrat (kuasa), iradat (berkehandak) ilmu ( berilmu), hayat (hidup), sama (mendengar), bashar (melihat), dan kalam (berfirman).

Di samping itu dalam ajaran Allah memiliki nama lain yang bersifat baik yang disebut dengan asma-ul khusna. Jumlah nama Tuhan ada 99, misalnya allatif, aljalil, alkarim, alahadu, alghaniyu. Dengan demikian, dapat dipastikan sifat-sifat kemuliaan Tuhan yang dikemukakan oleh Hamzah Fansuri dalam syair-syairnya itu berasal dari sifat wajib Allah dan asma-ulkhusna. Hamzah Fansuri sengaja memasukkan sifat wajib dan asmaulkhusna sebagai bahan pengajaran untuk mendudukkan Allah sebagai dzat yang mahamulia.

Hamzah Fansuri memahami Tuhan sebagai khalik yang berbeda dengan dengan makhluknya, disebutkannya / Upama kapas benang dan kain,/ Asalnya tunggal warnanya lain./ (I:43). Meskipun demikian, pendekatan yang sunguh-sungguh akan sampai pada kesamaan dengan Tuhan. Dalam syairnya Hamzah Fansuri mengemukakan antara lain: /Anak makhdum amalnya daim,/ Senantiasa sama dengan al-Karim./ (I: 4), /Buahnya lengkap tiada tersembunyi,/ Sungguhnya lengkap tiada berdinding./ (I: 6), /Mahw Raja, mahw Pengeran,/ Asal-mulanya satu tiada berlainan,/ (I: 16), /Itulah wujud menyatakan ahadiyat./ (I: 20), /Sungguhpun dua Tuhan dan sahaya,/ Dimanakan putus wujud dan cita// (I: 45), /La ilaha illa llah itu kesudahan kata,/ Tauhid akan ma'rifat semata-mata,// Hapuskan [hendak] perkara biasa,/ Hamba dan Tuhan tiadalah beda./ (II: 43). Dengan demikian, dapat diketahui bahwa Hamzah Fansuri termasuk penganut paham wujudiah, yang ingin mewujudkan kesatuan makhluk dengan khalik.

Dalam syairnya Hamzah Fansuri berulang-ulang menyebutkan kalimat tauhid, yaitu bacaan La ilaha illa llah dan $\mathrm{Hu}$ Allah. Kalimat tersebut terdapat pada Syair Perahu II bait 38, 39, 40, 41, 42, 43, 44, $45,46,47,48,49,50,51,52,53$. Sementara itu kalimat $\mathrm{Hu}$ Allah beberapa kali disebutkan dalam Perahu II, misalnya pada bait $57,58,59,60,61,62,63,64,65,66,67$, $68,69,70,71,72,73$. Pengulang dalam karya sastra menunjukkan sesuatu yang dianggap penting. Dalam hubungannya dengan ajaran Islam bacaan La ilaha illa llah yang bermakna 'tidak ada Tuhan yang pantas disembah kecuali Allah' memiliki kedudukan yang sangat penting sebab kunci keimanan seseorang terletak pada kesadaran seseorang untuk mengakui dan melisankan kalimat itu. Salah satu hadis menyatakan bahwa "Barang siapa yang pada akhir hayatnya sanggup mengucapkan La ilaha illa llah dijamin akan masuk ke dalam surga"

\section{Visi Keduniaan Hamzah Fansuri}

Dalam paham sufi kehidupan dunia dipahami sebagai suatu perjalanan menuju keabadian. Sementara itu, dalam kultur Jawa kehidupan di dunia digambarkan sebagai seseorang yang 'urip ning dunya mung mampir ngombe' artinya hidup di dunia ibatar hanya singgah untuk minum. Dalam pengertian ini kehidupan dunia sementara hanya beberapa saat saja, sedangkan kehidupan yang sebenarnya adalah alam kelanggengan atau keabadian.

Kefanaan dunia dan keabadian akhirat digambarkan oelh Hamzah Fansuri dalam syairnya sebagai berikut: /Alam itu bernama Misal,/ Ialah < .. > tiada kekal/ (I: 
37), /Tiada berubah ke Yaum mahsyar al jamman,/ (I:41), /Mencari dia, hai raji'un/ (I:46), /Ialah pohon sekalian raji'un,/(I:47), /Di dalam alam itupun sekalian datang,/ Di sanalah akhir sekalian dagang./ (I:51), /Sekaliannya itu akan hilang,/ Di padang Mirsad akan ditimbang/ (I:60), /Padang itulah terlalu luas,/ Berhenti di sana sekalianmu, an-nas,/ (I:61), /Dunianya di manakan lama?/ Sekarang menanti semuanya,/ (I:93), /Hartamu habis akan kau buang,/ Dari dahulu datang sekarang,/ Datang ajal jangan kaumamang./ (I:95), / Jadi 'unggun' api naraka,/ Jadi makanan kawa tujuh,/ Jadi mangsa Jaga Agung,/ Dusa tu 'ada' ‘apun lagi!/ (I:98).

Pada bagian lain Hamzah Fansuri mengingatkan manusia bahwa hidup di dunia itu tidak lama, akhirnya akan sampai juga ke alam akhirat. Di akhirat, terdapat siksa yang sangat pedih. Dengan demikian, manusia harus berhati-hati selama hidup di dunia, terutama memperbanyak ibadah dan berbuat baik.

Hal itu tercantum dalam beberapa bait syair, antara lain: /Tiada berapa lama hidupmu,/ Ke akhirat juga tempat diammu./(II:2), /Dalam dunia jangan tama'ah,/ Kedalam kubur berkhatwat sudah./ (II:29), /Kenal dirimu di dalam kubur,/ Badan seorang hanya terhancur,/ Dengan siapa lawan bertutur?/ Di balik papan badan tersungkur./ (II:30), /Ke akhirat juga tempat berpulang/(II:31), /Di dalam kubur terbaring seorang, / Munkar wa nakir ke sana datang,/ Me [na]nyakan engkau ada sembahyang./ (II:32), /Jikalau tiada segera terjawab,/ tongkatnya lekat tiada terhisab,/ Tambahan beberapa siksa dan azab,/ Akalnya itu hilang dan lenyap./ (II:33). /Munghkar wa Nakir itu bukan kepalang, / Suaranya merdu, keras dan garang,/ Tongkatnya besar terlalu panjang,/ Cambuknya banyak tiada terbilang / (II:34), /Kenal dirimu, hai anak dagang,/ Di balik papan tidur terlentang, //Kelam dan dingin bukan kepalang, / Dengan siapa lawan berbincang?/ (II:35). /La ilaha illa llah itu tempat berpegang,/ Petang dan pagi jangan kaumamang, / Di Padang mahsyar menjadi hulubalang,/ Allah dan rasul jua yang menolong /(II:47).

Hamzah Fasnuri memandang dunia sebagai suatu perjalanan panjang yang berujung pada kematian. Beliau menggunakan simbol-simbol yang terdapat dalam perjalanan. Bagi orang Melayu yang akrab dengan dunia kelautan simbol-simbol yang diangkat adalah simbol kemaritiman, yaitu perahu, laut, gelombang, karang, ikan, pelabuhan (bandar), pulau.

Syair Perahu I dan Syair Perahu II sudah cukup memberi gambaran bahwa penyair ingin menggambarkan manusia yang berada di dunia ini ibarat perahu yang sedang berlayar di lautan. Secara eksplisit pada Syair Perahu I dikemukakan lebih dari dua puluh lima simbol. yang berkaitan dengan perahu dan perlengkapannya misalnya /Lunasnya bernama Amar/ (I:9), /Tawakkul Akilun nama gegading/ (I:10), /Sengkarnya bernama Alif-Lam/ (I:12), /Pasaknya bernama Bintang/ (I:14), /Timbanya bernama Salawat/ (I:18), /Astaghfirullah [namanya] tambat,/ (I:20), /Ibadah al-Mubin nama haluan,/ / Ialah kunhi zat Tuhan,/ (I:22), /Sifat Allah nama tengahnya//Ialah hamba amat percaya,/ (I:25), Asma al-Latif nama buritan,/ (I:28), /Ayn al-Yakin nama kemudi,/ Ialah banyak bersembah dan puji,/ (I:31), /Bait Maulana nama kurung,/ (I:35), /Amanat bi-Llahi nama tali-temberang,/ (I:39), / Panji Muhammad nama tiang,/ (I:52), / La tataharraku nama layar,//Ialah kahhar kerjanya sukar,/ Mengelilingi alam sabar-sabar,/ (I:58), /Rijal al-Asyikin nama nakhodanya,/ (I:64), /Inna li-Llah nama pembawanya,/ (I:67), /Rajil wajib nama sambut layang,/ (I:70), /Ruh al-Kudus nama [nya] dandan,/ (I:73), Tarikat ikhlas nama [nya] sauh,/ (I:76), /Sahil Allah nama pangkalan,/ (I:79), /Samadiyah nama sampan// Ialah daim menyerang topan,/ (I:82), /Barakat Allah nama dayung,// Sekalian umat minta tolong,// Beroleh syafaat di dalam lorong,// Ialah unggas melata 
gunung,/ (I:85.. Pada Perahu I juga disebutkan /'Anyut para'u dari 'ulu,/ 'Asam cuka makanan pari,// Tambai kutahu dari kapada guru,/ Tarabuka pun barahi,/ (1), / Yogya kamu ketahui asalnya perahu itu,/ (I:5),

Sementara itu, pada Syair Perahu II dikemukakan sembilan buah perumpamaan sebagai berikut: /Wei muda, kenal dirimu,/ Ialah perahu tamsil tubuhmu,/ Tiadfa berapa lama hidupmu,/ Ke akhirat juga tempat diammu./ (II:2), /Teguh-teguh alat perahu,/ (II:6), /Pedoman betul perahumu laju,/ Selamatlah engkau ke pulau itu./ (II:13), /Silan itu terlalu dalam,/ Di sanalah perahu tampar dan karam,/ (II:15), /Anginnya keras ombaknya rencam,/ Timbangi perahu jangan tenggelam./ (II:21), /Belayar perahu sidang budiman [nya],/ Berlayar itu dengan kelengkapannya./ (II:23), Wujud Allah nama perahunya// Ilmu Allah akan kurungnya,/ Iman Allah nama kemudinya,/ Yakin akan Allah nama pawangnya./ (II:24).

Hamzah Fansuri memberikan pesan agar berhati-hati dalam hidup di dunia. Beberapa pesan yang dikemukakan dalam syairnya berkaitan dengan masalah harta. Artinya, manusia harus berhati-hati agar jangan sampai teperdaya oleh harta. Dengan kata lain kederhanaan hidup perlu diutamakan.

Beberapa bait syair yang mengungkapkan hal tersebut adalah /Mengelilingi alam sabar-sabar/ (I:58), /Artamu sarat banyak kaupegang/ (I:40), /Hartamu habis akan kaubuang/ (I:59). /Ingat-ingat jangan kaumamang,/ Hartamu habis [akan] kaubuang,/ Supaya betul jalanmu pulang / (I:69), /Jangan bermakan warna dan cahaya,/ Alam itu lagikan berpindah/ (I:72) /Ingat-ingat sekalian yang lupa,// Olehmu jangan diperbesar neraka/ (I:94), /Hartamu habis akan kaubuang,/ Dari dulu datang sekarang,/ Datang ajal jangan kaumamang./ (I:95), /Dalan dunia jangan tama'ah,/ Kedalam kubur berkhalwat sudah./ (II:29), /Diam di dunia banyaklah mamang,/ Ke akhirat juga tempat berpu- lang,// Janganlah dikasih emas dan uang,/ Itulah membawakan badan terbuang / (II:31), /Penjara dunia padahkan kekal,/ Terlalu manis pada orang yang bebal,/ Budak kecil sangat nakal,/ (II:80).

\section{Konsep Hamzah Fansuri untuk Men- dekatkan Diri kepada Tuhan}

Mendekatkan diri kepada Allah merupakan salah satu ajaran Islam. Hadis Nabi Muhammad saw. menyebutkan "Allah azza wajalla berfirman: Aku dalam sangkaan hamba-Ku kepada-Ku, dan aku kepadanya jika ia mengingat Ku. Maka jika ia mengingat-Ku pada dirinya, Aku akan mengingatnya pada diri-Ku. Dan jika ia mengingat-Ku dalam suatu kelompok maka aku akan mengingatnya dalam satu kelompok yang lebih baik dari mereka. Dan jika ia mendekat pada-Ku sejengkal maka Aku akan mendekatnya sehasta, dan jika ia mendekat pada-Ku sehasta maka Aku akan mendaktanya sedepa, dan jika ia datang pada-Ku dengan berjalan maka Aku akan mendatanginya dengan cepat-cepat" (Bahreisy, 1980:378).

Usaha mendekatkan diri kepada Allah menurut Hamzah Fansuri dalam syairnya dilakukan dengan beberapa cara, yaitu (1) mengenali diri sendiri, (2) mengenali zat Allah dan sifat-sifat-Nya, (3) memperbanyak zikir yaitu ingat pada kekuasaan dan kebesaran Allah dengan mengucapkan puji-pujian, (4) memperbanyak ibadah, amal salih, (5) menjauhkan diri dari perbuatan yang tidak diperkenankan Allah, dan (6) selalu ingat akan kematian.

Mengenali diri sendiri mrupakan salah satu cara untuk dapat mengenal Tuhannya. Dalam ilmu tasawuf dikatakan man 'arafa nafsahu faqad arafa rabbahu, artinya barang siapa mengenal dirinya sendiri, sesungguhnya ia telah mengenal Tuhannya. Di sebutkan "Hu Allah Tuhan yang ada, / Mengenal diri janganlah lupa, / Kaim daim senantiasa, / Di padang Mahsyar beroleh laba./ (II:64)

Baris pertama menyebutkan salah satu sifat Allah yaitu ada (wujud). Baris kedua 
secara eksplisit mengingatkan agar mengenal diri sendiri. Baris ketiga menunjukkan cara yang dapat dilakukan yaitu kaim daim. Kaim boleh jadi berasal dari qaama yang berarti berdiri atau istiqamah yang berarti teguh dalam pendirian. Sementara itu, daim dalam KBBI (1995:205) berarti tetap selama-lamanya, langgeng, kekal atau abadi. Secara umum pengarang mengajak untuk berdiri dalam arti salat atau mungkin istigamah artinya teguh kepada pendirian dan tidak mudah goyah dalam memegang agama. Baris keempat menunjuk pada pahala yang akan diperoleh seorang yang istiqamah dan tidak tergoda oleh kelezatan atau kenikmatan duniawi. Kelak di Padang Mahsyar tempat manusia dikumpulkan setelah dibangkitkan dari dalam kubur mereka akan mendapatkan keberuntungan. Ajakan untuk mengenal diri sendiri banyak ditemukan dalam baitbait yang lain. misalnya, menyatakan/Hai muda, kenal dirimu/ (II:2), sedangkan pada Syair Perahu II bait 30 dikemukakan /Kenal dirimu di dalam kubur/ (II:30).

Zikir adalah ingat pada Allah dengan hati, lisan, atau perbuatan. Salah satu cara berzikir adalah mengucapkan puji-pujian dan menyebutkan nama atau sifat Allah. Puji-pujian yang sering dilafalkan adalah kalimat tayyibah, yang terdiri dari tahlil (laa ilaaha illa Allaah), tasbih (Subhaanallaah), tahmid (Alhamdulillaah), takbir (Allaahu Akbar). Sementara itu, nama dan sifat Tuhan yang sering dipakai untuk puji-pujian adalah asmaa ul husna. Di samping itu, terdapat puji-pujian yang lain seperti istighfar dan salawat. Istighfar adalah permohonan ampun kepada Allah dengan melafalkan kalimat astahgfurullah hal adlim, sedangkan salawat berisi doa untuk Nabi Muhammad. Lafal salawat adalah Allahumma salli ala Muhmmad.

Di dalam Syair Perahu I terdapat lebih dari lima pujian, misalnya: Allahumma, salli 'alaihi wa salam (I:3), tasybih (I:15), salawat (I:18), takbir dan tahlil (I:19), astaghafirullah (I:20). Sementara itu, pada Syair Perahu II disebutkan La ilaha illa llah tali yang teguh (II:12), La ilaha illa llah juga engkau ikut (II:14), istigfar Allah akan layarnya, Allahu Akbar nama anginnya, subhanallah akan lajunya (II:27), La ilaha illa llah itu firman Tuhan (II:38), La ilaha illa llah itu pertama kata (II:39), La ilaha illa llah itu jangan dipermudah (II:40). Bacaan tahmid yaitu, La ilaha ila llah ternyata disebutkan beberapa kali pada bait 40, 41, 42, 43, 44,45,46,47,48,49,50,51,52,53, 73.

Di dalam ajaran Islam dijumpai perintah untuk memperbanyak membaca kalimat tayyibah yang berisi istighfar (permohonan ampun) dan puji-pujian kepada Allah. Istighfar atau permohonan ampun dikemukakan dalam salah hadsi 'an abii Hurairah qaala: sami'tun nabiyya sh yaquulu: wa lillahi innii la astaghfiruha wa atuubu ilaihi fi yaumin aktsara min sab'iina marratan, artinya " Dari Abu Hurairah berkata: Aku mendengar Nabi saw.bersabda: Demi Allah aku meminta ampun kepada Allah dan bertobat kepada-Nya dalam sehari lebih dari 70 kali. Sementara itu, tentang puji-pujian disebutkan dalam hadis man qaala subhaanallahi wa bihamdihi fi yaumin miata marratin huthat 'anhu khathaayaahu wa inkaanat mistla zabadil bahri, artinya " Barang siapa membaca (artinya); Mahasuci Allah dan dengan segala puji untuk-Nya dalam sehari 100 kali maka akan diampuni kesalahannya walaupun sebanyak buih di lautan (Bahreisy,1980:382-390)

Ibadah merupakan salah satu cara untuk mendekatkan diri. Dalam ajaran Islam menurut Hafidzy (1980/81:6) terdapat rukum Islam. Pokok-pokok keselamatan itu ada lima, yaitu (1) mengucapkan dua kalimat syahadat, (2) mengerjakan shalat lima waktu, (3) mengeluarkan zakat, (4) puasa pada bulan Ramadan, dan (5) mengerjakan ibadah haji. Kelima rukun itu syarat dengan ritual usaha mendekatkan diri pada Allah. Melalui salat, misalnya, manusia berusaha mendekatkan diri dan berdialog dengan Tuhan. Di samping itu, ajaran islam juga menuntunkan manusia untuk banyak beramakl salih seperti menyatuni kerabat, anak yatim dan 
fakir miskin. Dalam surat Al Jatsiyah:15 disebutkan Man 'amila shaalihan falinafsihi wa man sa a fa'alaihi stumma ila rabbikum turja'uun, artinya "Barang siapa berbuat kebaikan maka akan kembali kepadanya, dan barang siapa berbuat kejahatan juga akan kembali kepadanya, dan kepada Tuhanlah engkau akan kembali". Dalam bagian lain, yaitu Al An'am:160 Allah berfirman Man jaa a bil hasanati falahu 'asru anstaalihaa wa man jaa a bissayyiati falaa yujza illa mistliha wahum laa yudhlamuun, artinya 'Barang siapa berbuat kebajikan baginya pahala sepuluh kali lipat, dan barang siapa berbuat kejelekan baginya balasan yang setimpal".

Ibadah dan amal salih disebutkan oleh Hamzah Fansuri dalam syairnya lebih dari empat kali pada Syair Perahu I, misalnya anak makhdum amalnya daim (I:4), halal dan ibadat tiada bebal (I:13), zakir dan mazkur yogya diperbuat (I:20), ibadat al-Mubin nama haluan (I:22). Sementara itu, pada Syair Perahu II tentang ibadah dan amal salih disebutkan lebih dari tujuh kali, misalnya taharat dan istinja nama lantainya (II:25), taat dan ibadat anak dayungnya (II:26), salat akan nabi tali bubutannya (II:27), Syahadat itu pertama kata, Fardu sembahyang, zakat, puasa, Naik haij apalah kita, Kelima rukun di sana nyata (II:36), periksa amal taat ibadat (II:70), Taat ibadat jua kauingat (II:72), sujud dan ta'zim pada tengah medan (II:77).

Menjauhkan diri dan mencegahnya dari perbuatan yang tidak baik dikenal dengan istilah nahi mungkar. Oleh karena itu, nahi mungkar dapat ditujukan kepada diri sendiri atau kepada orang lain. Dalam ajaran Islam perbuatan yang tidak baik adalah perbuatan yang tidak diridai oleh Allah atau perbuatan yang dilarang oleh Allah, misalnya fasik (berbuat keji). Di dalam surat Albaqarah: 26-27 disebutkan “... Dan tidak ada yang disesatkan Allah kecuali orang-orang yang fasik; (yaitu) orang-orang yang melanggar perjanjian allah sesudah perjanjian itu teguh, dan memutuskan apa yang diperintahkan Allah (kepada mereka) untuk mengubungkannya dan membuat kerusakan di muka bumi. Mereka itulah orang-orang yang rugi".

Di dalam Syair Perahu I istilah 'fasik' disebutkan sebagai berikut, yaitu haram juga yang kau kenal (I:13), /Angin takutkan sekalian fasik,/ Siksanya sangat terlalu munsarik, /Di luar kandang arbab al-rizik, /Itulah jemputan datuk dan nenek/ (I:87).

Untuk mengusahakan hal itu, seorang sufi membiasakan hidup suci dengan jalan mengurangi kesenangan duniawi dan menjauhkan diri dari tuntunan nafsu. Untuk itulah performansi mereka bersahaja, sederhana, dan menjauhi kemewahan.

Tentang membiasakan hidup suci dikemukakan dalam Syair Perahui I disebutkan /Mabuk itu bukannya kasih,/ / Ialah kelakuan tajali dan tasybih,/ Itulah cermin terlalu bersih,/Bayang-bayangnya sangat mengalih/ (I:15), /Kelakuan yang benar [yogya kautuntut]/ (I:77).

Sementara itu, mengenai usaha mengenang hawa nafsu dan hidup sederhana banyak dikemukakan dalam syair-syair itu. Pada Perahu I disebutkan lebih dari enam kali, misalnya /Mengelilingi alam sabar-sabar/ (I:58), /Artamu sarat banyak kaupegang/ (I:40), /Hartamu habis akan kaubuang/ (I:59). /Ingat-ingat jangan kaumamang,/Hartamu habis [akan] kaubuang,/Supaya betul jalanmu pulang / (I:69), /Jangan bermakan warna dan cahaya,/ Alam itu lagikan berpindah/ (I:72) /Ingat-ingat sekalian yang lupa,/ Olehmu jangan diperbesar neraka/ I:94), /Hartamu habis akan kaubuang,/ Dari dulu datang sekarang,/ Datang ajal jangan kaumamang./ (I:95). Pada Syair Perahu II disebutkan tiga kali, yaitu /Dalam dunia jangan tama'ah,/ Kedalam kubur berkhalwat sudah./ (II:29), /Diam di dinia banyaklah mamang,/ Ke akhirat juga tempat berpulang,/ Jangalah dikasih emas dan uang,/ Itulah membawakan badan terbuang / (II:31), /Penjara dunia padahkan kekal,/ 
Terlalu manis pada orang yang bebal,/ Budak kecil sangat nakal,/ (II:80).

Hidup suci, tidak menuruti hawa nafsu, sederhana, dan tidak bermegahmegahan merupakan ajaran Islam. Ajaran seperti tercermin dalam kehidupan Nabi Muhammad yang sangat bersahaja. Beliau, sebagai pemimpin Islam tidak memiliki istana yang megah dan kekayaan yang berlimpah. Keserdahanaan beliau digambarkan dalam sikap dan perilaku beliau sehari-hari. Disebutkan dalam hadis bahwa "beliau tidak makan sebelum lapar dan beliau menghentikan makan sebelum kenyang".

Menurut Hanzah Fansuri untuk menjalani hidup sebagai seorang sufi, harus melalui tahapan yang disebut tarikat, yang berarti jalan menuju kedekatan dengan Allah. Ada lima tataran yang dilalui yaitu (1) syariat, (2) tariqat, (3) hakikat, dan (4) makrifat.

Pada Syair Perahu I disebutkan 3 hal yang berhubungan dengan syariat, yaitu /Berbuat syariat sekalian Islam/ (I:11), / Cintanya hendak menghadapkan kiblat,/ (I:18), /Syariatnya kekal telah tertammu,/ (I:54). Sementara itu, pada Perahu II tidak terdapat pernyataan eksplisit yang terkait dengan syariat.

Tentang tariqat dalam syair Perahu I dikemukakan dua hal yaitu/Syaikh maulana bangsanya karim,/Menunjukkan jalan ke jannat an-naim,/ (I:4), /Tarikat ikhlas nama[nya] sauh/ (I:76). Selanjutnya mengenai hakikat, pada Syair Perahu I terdapat lima pernyataan yang terkait dengan hal itu, yaitu: /Ialah berhakikat kaca dan permata./ (I:24), /Itulah bernama Hakikat Insani./ (I:29), /Hakikatnya daim dengan Jannat ar-Rabi./ (I:31), /'Huwa rizk baki li-asykin' hakikatnya,/ (I:67), /Hakikat itu yogya kaukenal,/ I:(81).

Sementara itu, tentang makrifat pada Syair Perahu I dikemukakan dua hal, yaitu /Takbir dan taklil yogya diperbanyak,/Supaya marifatmu seperti minyak,/ (I:19), /Kekasih Tuhan yang kenal Dia,/ Kedudukannya senantiasa dengan
Termulia,/ Ialah mendapat marifat yang sedia,/ Di sanalah perhimpunan sekalian kita./ (I:55). Pada Perahu II dikemukakan tujuh hal yang terkait dengan makrifat, yaitu /La ilaha illa llah itu pertama kata,/ Tauhid akan ma'rifat semata-mata,/ (II:39), /La ilaha illa llah itu kesudahan kata,/ Tauhid akan ma'rifat semata-mata,/ Hapuskan [hendak], perkara basa,/ Hamba dan Tuhan tiadalah beda/ (II:43), /La ilaha illa llah itu tempat bergantung,/ Tauhid akan ma'rifat menyudahi untung,/ Jika kurang ingat lepaslah burung,/ Terbangh ke udara mencari gunung./ (II:46), /Betulkan ma'rifat kayuhkan rakit./ (II:50), / La ilaha illa llah itu ma'rifat yang teguh,/ (II:51), /Hu Allah juga kaukenal,/ Betulkan ma'rifat kepada yang Ghana,/ Hidup matimu boleh sempurna,/ Kepada Allah sangat berguna./ (II:57), /Tauhid akan marifat janganlah musykil./ (II:66).

Untuk mencapai tiap tataran seorang sufi dibimbing oleh seorang guru. Untuk itulah dalam paham sufi, guru memegang peranan yang amat penting, yaitu membimbing muridnya mencapai tingkatan yang paling tinggi. Karena kedudukannya yang sangat penting, beberapa paham memandang guru sebagai wali Allah yang dapat menjadi pembimbing, sekaligus wasilah atau perantara menuju kedekatan pada Allah. Guru dalam pengertian itu juga akan memberikan safaat atau keringanan tatkala manusia itu kelak menghadapi siksa di akhirat. Untuk itulah guru dalam pahan sufi menduduki peran yang sangat penting.

Pada Perahui I dikemukakan delapan hal yang berhubungan dengan guru, yaitu /Tambai kutahu dari kapada guru,/ (I:1), /Kabar ni sahi mangulana./ (I:2), /Syaikh maulana bangsanya karim,/ Menunjukkan jalan ke jannat an-naim,/ (I:4), /.........../ Lengkap rata, sekalian talib./ (I:42), / Markaz al-Dawair nama malim angin,/ Ialah daim bertipu bermain,/ Kedudukannya bukan di belakang rakibun,/ Ialah tahu ketika berubah angin./ (I:49), / Malim itu pandai berbudi,//Melayarkan 
laut tiada bertepi,/ Sekalian kita dari sana jadi,/ Airnya tenang amatnya suci./ (I:50). /Melayarkan di sana tuan malim,/ Tahukan jalan terlalu karim,/ Amat laik melayarkan yatim,/ (I:53), /Nakhoda itu bukannya batin,/ Sekalian negeri tempatnya bermain,/ Menyuburkan dirinya kepada arifin,/ Ialah tahu hakikat angin./ (I:65). Sementara itu, pada Syair Perahu II dikemukakan pernyataan berikut $/ \mathrm{Hu}$ Allah itu amat melihat,/ Taat ibadat jua kauingat,/ Carilah guru akan ba'yat,/ Supaya tahu jalan akhirat./ (II:72).

Menurut Simuh (1995:30) tasawuf murni bertujuan untuk menjadi insan kamil dalam arti waliullah, yakni orangorang yang dapat mencapai penghayatan makrifat dan setiap saat dapat berdialog langsung dan menjadi kekasih Tuhan. Dalam bagian lain Simuh (1995:90) menyebutnya wali atau waliyullah yaitu orang yang telah dianugerahi penghayatan makrifat kepada Allah dan menjadi orang suci yang dikasihi Allah.

Dalam termonologi kaum sufi adalah wali Allah itulah guru yang dapat membimbing daalam tarikat. Mereka pastilah orang suci yang tidak diragukan lagi keulamaannya dan kesalihannya. Mereka dapat disejajarkan dengan para ulama yang disebutkan dalam hadis nabi riwayat Ibu Majah sebagai berikut: al ulamaa $u$ warasatul ambiyaa I tuhibbuhum ahlassamaa I wa tas taghfiru lahumu lkhitaamu fil bahri idza maatuu ilaa yaumil qiyaamati, artinya "Ulama itu pewaris para nabi, ahli langit (para malaikat mencintai mereka dan ikan-ikan di laut memintakan ampun untuk mereka bilamana mereka mati hingga hari kiyamat" (Qohar, 2002:408). Ulama atau wali sangat tinggi dan terhormat kedudukan, sehingga mereka pantas menjadi guru untuk membimbing manusia meniti tahapan-tahapan dalam ilmu tasawuf.

Dalam ilmu tasawuf kedudukan guru sangat penting sehingga mengharuskan setiap seorang yang ingin menjalani hidup sufi dalam bimbingannya. Tanpa bimbing- an seorang guru seseorang dapat tersesat dalam mempelajari ilmu tasawuf. Untuk itulah muncul tradisi memberikan penghormatan yang luas biasa kepada seorang guru. Bahkan, di beberapa aliran tarikat, ada kecenderungan figur guru cenderung dikultuskan.

\section{SIMPULAN}

Visi ketuhanan Hamzah Fansuri tidak berbeda dengan visi para sufi yang ingin mendekatkan diri kepada Tuhan dengan sedekat-dekatnya. Tuhan menurut Hamzah Fansuri memiliki sifat-sifat kemuliaan. Tuhan menurunkan pedoman berupa kitab dan firman-firman. Di dalamnya terdapat hukum-hukum yang harus ditaati oleh umat manusia. Dalam pandangan Hamzah Fansuri pendekatan diri kepada Tuhan dapat mencapai tataran tertinggi yaitu menyatunya hamba dengan khalik.

Hamzah Fansuri memandang dunia sebagai suatu yang bersifat fana, sedangkan akhirat merupakan sesuatu yang bersifat baka. Dalam hal ini Hamzah Fansuri memberikan simbol kehidupan dunia dengan perahu yang berlayar. Dalam perjalanan itu berbagai bahaya mengancamnya, yaitu nafsu duniawi. Gambaran tentang siksa akhirat mengingatkan manusia untuk berhati-hati dalam hidup di dunia yaitu dengan cara banyak beribadah dan berbuat baik.

Cara untuk mendekatkan diri kepada Tuhan menurut Hamzah Fansuri ialah (1) ingat akan diri sendiri, (2) berzikir dan mengucapkan puji-pujian, (3) beramal salih, (4) mengekang hawa nafsu dan hidup sederhana, (5) nahi mungkar. Ada empat tataran untuk mencapai martabat tertinggi, yaitu yaitu syariat, thariqat, hakikat, dan makrifat. Untuk mencapai tataran tersebut diperlukan pembimbing yaitu guru.

Akhirnya, diharapkan hasil kajian dapat dijadikan referensi bagi masyarakat untuk memperluas wawasannya tentang tasawuf. Dengan demikian, masyarakat 
dapat memberikan penilaian dan penghakiman yang tepat terhadap berbagai paham tasawuf yang berkembang selama ini.

\section{UCAPAN TERIMA KASIH}

Artikel ini disarikan dari hasil penelitian mandiri yang dilaksanakan di Fakultas Bahasa dan Seni dengan anggaran dana DIPA FBS UNY tahun 2008. Ucapan terima kasih kami sampaikan kepada DPP Penelitian FBS UNY yang telah memfasilitasi penelitian ini hingga selesai. Ucapan terima kasih juga kami sampaikan kepada reviewer yang telah mengoreksi dan memberi masukan terhadap artikel ini.

\section{DAFTAR PUSTAKA}

Bahreisy, Hussein. 1980. Himpunan Hadits Pilihan Shahih Bukhari. Surabaya: Al Ikhlas.

Braginsky, V.I. 1993. Tasawuf dan Sastra Melayu. Jakarta: RUL.

Depdikbud. 1995. Kamus Besar Bahasa Indonesia. Jakarta: Balai Pustaka.

Depdiknas. 2002. Instruksi Menteri Nasional Republik Indonesia Nomor: I/U/2002 tentang Pelaksanaan Akuntabilitas Kinerja di Lingkungan Departemen Pendidikan Nasional. Jakarta: Depdiknas Biro Hukum dan Organisasi.

Depag. 1995. Al Quran dan Terjemahannya. Yogyakarta: Dana Bakti Wakaf UII.
Depag. 2000. Al-'Aliyy: Al-Quran dan Terjemahannya. Bandung: Diponegoro.

Hadi W.M., Abdul. 1995. Hamzah Fansuri: Risalah Tasawuf dan Puisi-puisinya. Bandung: Mizan.

Hafidzy, E. Hasbullah. 1980/1981. Rukun Iman (Pokok-pokok Kepercayaan dalam Islam). Jakarta: Kartika.

Hafidzy, E. Hasbullah. 1980/1981. Rukun Islam. Jakarta: Kartika.

Hatta, Bakar. 1982. Sastra Nusantara: Suatu Pengantar Studi Sastra Melayu. Jakarta: Ghalia Indonesia.

Mulkhan, Abdul Munir. 2002. Syekh Siti Jenar: Pergumulan Islam-Jawa. Yogyakarta: Bentang Budaya.

Pimpinan Pusat Muhammadiyah. 1967. Himpunan Putusan Tarjih. Yogyakarta: Persatuan.

Qohar, H.M. Hasan Abdul. 2000. Kumpulan Khoptbah Jumat 1 Tahun. Yogyakarta: Absolut.

Simuh. 1995. Sufisme Jawa Transformasi Tasawuf Islam ke Mistik Jawa. Yogyakarta: Bentang Budaya.

Sukmono. 1973. Sejarah Kebudayaan Indonesia. Yogyakarta: Kanisius.

Uswatun Hasanah. 1989. No. 046/Th.I, Shafar $1410 \mathrm{H} /$ September $1989 \mathrm{M}$.

Yunus, I Ba dan Farid Ahmad. 1993. Sosiologi Islam \& Masyarakat Kontemporer. Bandung: Mizan. 